\title{
THE GELANDANGAN OF JAKARTA: POLITICS AMONG THE POOREST PEOPLE IN THE CAPITAL OF INDONESIA*
}

\author{
Parsudi Suparlan
}

This paper tries to show how a specific urban environment shapes the way its inhabitants participate in politics, the goals they hope to achieve, and their conception of what politics itself is all about. The environment referred to is that of the poorest people in Jakarta, called orang gelandangan.

The term gelandangan is derived from the word gelandang, which means "always on the move" and "never settling in one place." For a long time the better-off Jakarta citizens have concluded that there are groups of people living in Jakarta without stable jobs or stable places to live, yet maintaining a specific way of life. They call these people orang gelandangan and stereotype them as shiftless, dirty and untrustworthy.

My data reveal that such stereotypes are false, for they show that the gelandangan do work hard in an attempt to make at least a subsistence-level livelihood. Some of them even have relatively stable jobs as street-vendors, secondhand clothes peddlers, street-sweepers or hawkers. Some of the women work as prostitutes. Furthermore, the majority of them have relatively stable places to stay or sleep, such as sheltered places along the streets and alleys, store verandahs at night or empty railroad cars, even spaces under bridges. Moreover, there are certain residential rules which apply to the gelandangan among themselves. For example, a certain gelandangan area is "off limits" to other gelandangan unless special permission is given to the newcomers by the settled gelandangan of that area. Only with such permission may the newcomers settle or become gelandangan in the vicinity.

In fact, in their own ways, the gelandangan form communities stable enough to have a muted politics of their own, shaped by the crushing environment in which they try to survive. In the following pages, I will try to show what they hope and can achieve in the political sphere and why the limits on their actions are so narrowly circumscribed.

The gelandangan community I studied is located only some hundred meters from the State Palace which lies on Merdeka Utara Street. On the western side of the community's area is a drainage canal which is

* I am indebted to the Asia Society for a grant to write this paper, and also to Dr. Benedict R. O'G. Anderson, Cornell University. I also wish to thank Dr. Harsja W. Bachtiar, University of Indonesia, Jakarta, for his advice during my field work in 1961 , and to Dr. Edward M. Brumer, University of Illinois, for his comments on the first draft of this paper. 
usually used as a toilet and sometimes for washing clothes. On the eastern side are the National Museum, National Defense buildings, and other government offices. In the early $1950 \mathrm{~s}$ this area was a place of tall grass, and only fifteen gelandangan lived there. By 1960, however, the grass had been cleared and many new members had come to settle. (Only seven of the original fifteen inhabitants remained, five men and two women.) The influx had brought trouble to the community; some of the newcomers were prostitutes, gamblers and thieves, who preyed on their neighbors. Finally, the local administrative offices (including the army) and various government officials stepped in, and on October 17,1960 , the prostitutes, gamblers, thieves and others involved in criminal activities were ordered to modify their way of 1 ife or they would be thrown out of the area.

Most of the gelandangan originally came from the rural areas or from kampong on the edge of towns in West and Central Java. But some had migrated from rural areas of Sumatra, Kalimantan (Borneo) and East Java. ${ }^{3}$ (Some of the people I interviewed moved directly to Jakarta from their place of birth while others moved to progressively larger towns first before finally coming to Jakarta. The following tables show how the gelandangan community grew and changed over the years.

Table I

Sex and Age Composition of Gelandangan Community Over Time

\begin{tabular}{lccccc}
\hline \hline \multicolumn{1}{c}{ Period } & Men & Women & $\begin{array}{c}\text { Male } \\
\text { Children }\end{array}$ & $\begin{array}{c}\text { Female } \\
\text { Children }\end{array}$ & Total \\
\hline 1950/51 & 13 & 2 & - & - & 15 \\
Oct. 17, 1960 & 37 & 24 & 4 & 2 & 67 \\
Nov. 15, 1960 & 35 & 26 & 7 & 4 & 82 \\
July 1961 & 48 & 33 & 8 & 9 & 98 \\
\hline
\end{tabular}

When I revisited the area in 1963 , it had expanded to include more territory and to accommodate a larger number of inhabitants. Whereas in 1961 there had been 98 people, by 1963 the number had increased to 201 (99 newcomers and four births). No deaths had occurred and no one had moved out of the territory in the intervening years.

A11 of the 201 members of the community had become citizens of Jakarta and carried identification cards. Administratively the community had been made into an RT (Rukun Tetangga), an urban administrative division denoting a community of households. Their new citizenship was significantly related to their survival, for all members of an RT had 1 and and had the right to receive primary distributions of primary commodities, such as food, from the government. (During this period, the government prices for such commodities were much lower than market prices.)

1. Bert N. Adams, "Kinship Systems and Adaptations to Modernization," Studies in Comparative International Development, IV, No. 3 (1968-69), pp. 47-60. 
Table II

Regional Origins of Gelandangan Migrants Over Time

\begin{tabular}{|c|c|c|c|c|c|c|c|c|}
\hline \multirow{3}{*}{$\begin{array}{c}\text { Place of } \\
\text { Origin }\end{array}$} & \multicolumn{8}{|c|}{ Period Registered } \\
\hline & \multicolumn{2}{|c|}{$1950 / 51$} & \multicolumn{2}{|c|}{ Oct. 17,1960} & \multicolumn{2}{|c|}{ Nov. 15,1960} & \multicolumn{2}{|c|}{ July 1961} \\
\hline & Men & Women & Men & Women & Men & Women & Men & Women \\
\hline \multicolumn{9}{|l|}{ North Sumatra } \\
\hline Kotaraja & - & - & - & - & - & - & 1 & - \\
\hline Medan & 1 & - & 1 & - & 1 & - & 1 & - \\
\hline \multicolumn{9}{|l|}{ South Sumatra } \\
\hline Palembang & - & - & 1 & - & 1 & - & 1 & - \\
\hline \multicolumn{9}{|l|}{ West Java } \\
\hline Banten & - & - & 3 & - & 1 & - & 2 & - \\
\hline Jakarta & 2 & - & 3 & - & 4 & 5 & 7 & 5 \\
\hline Bogor & 2 & - & 8 & 5 & 9 & 3 & 10 & 6 \\
\hline Bandung & - & - & 4 & 2 & 4 & 2 & 3 & 1 \\
\hline Purwakarta & - & - & - & - & 1 & - & 1 & - \\
\hline Cirebon & - & - & 4 & 7 & 5 & 6 & 10 & 8 \\
\hline \multicolumn{9}{|l|}{ Central Java } \\
\hline Pekalongan & 1 & - & 6 & 8 & 6 & 10 & 8 & 12 \\
\hline Semarang & - & - & - & - & - & - & 1 & - \\
\hline Salatiga & - & - & - & 1 & - & - & - & - \\
\hline Magel ang & - & - & 1 & - & 1 & - & 1 & - \\
\hline Yogyakarta & - & - & 1 & - & 1 & - & 1 & - \\
\hline \multicolumn{9}{|l|}{ East Java } \\
\hline Ngawi & - & - & - & 1 & - & - & - & - \\
\hline \multicolumn{9}{|l|}{ South Borneo } \\
\hline Balikpapan & 1 & - & 1 & - & 1 & - & 1 & - \\
\hline Total & 7 & - & 37 & 24 & 35 & 26 & 48 & 33 \\
\hline TOTAL & & 7 & & & & & & \\
\hline
\end{tabular}

Conditions of Life

\section{Housing}

The gelandangan's housing possibilities were meager enough, but the group could be divided into those with huts and those without. Among these huts, distinctions could be made between "semi-permanent huts" (permanent residences, but with largely impermanent building materials), "semi-temporary huts" (semi-temporary residences with less permanent materials), and "temporary huts" (makeshift shacks). Those gelandangan without huts of any kind could be divided into those who slept in the open air and those who made some type of shelter for the night out of empty cartons, baskets, and so forth. Their sleeping arrangements can be described as follows: 
Table III

Sleeping Places of Hutless Gelandangan, 1963

\begin{tabular}{lcc}
\hline & $\begin{array}{c}\text { Those with } \\
\text { Families }\end{array}$ & $\begin{array}{c}\text { Those without } \\
\text { Families }\end{array}$ \\
\hline Shed & 25 & 8 \\
Yard: a. with shelter & 2 & 2 \\
$\quad \begin{array}{l}\text { b. without shelter } \\
\text { Verandah of depot (on drainage canal, } \\
\text { owned by non-resident Chinese) }\end{array}$ & 2 & 2 \\
Food stails & 2 & 1 \\
\hline
\end{tabular}

\section{Livelihood}

In front of the huts one could always see heaps of papers, broken glass, small pieces of zinc, wires and so forth. These scraps reflect the gelandangan's search for a livelihood. The income of the gelandangan is not stable, but depends on luck and individual diligence in collecting "valuable" items. The jobs of the gelandangan I studied can be classified as follows:

1. Leftover valuable collector

2. Becak driver

3. Street-vendor

4. Agent buying and selling leftover valuable items

5. Collector of valuable items on the canal and river banks

6. Food-seller and warung [small foodstall]-owner

7. Sweepstakes ticket-seller

8. Handicraft-maker

9. Street-sweeper for the Department of Pub1ic Works

10. Guard watching over valuables such as boxes belonging to street-vendors

The number of people who collected leftover valuable items was thirty-three, some married and some not. Some had a particular supplier of the materials sought, while others scrounged anywhere and on their own. Examples of the former group were those who collected paper from janitors out of office trash. The collectors would separate and classify the papers by type: daily newspapers, stencilled paper, garbage paper (pieces of paper between 0.5 and 1 centimeter wide, length uncertain), and cutting paper (papers between 2 centimenters and 5 centimeters wide which can be glued together to make wrapping paper). After the papers were classified, they were sold by specified bulks. A typical day for a married couple with a supplier can be described as follows: In the morning the husband arranges and prepares the leftover papers collected the day before from the supplier. The wife cooks breakfast and then goes to market. Once home from market, the wife helps the husband and in the afternoon the husband collects more papers. The wife continues to sort out and arrange the papers and occasionally chats with her neighbors.

The number of those who did not have particular suppliers totaled thirty persons, eighteen married and twelve unmarried. They collected not only papers but also used materials such as cans, pieces of zinc, and so on. A typical day for a married couple without a particular 
supplier might be as follows: If the husband is diligent, he begins collecting trash at 6 a.m., returning home at $10 \mathrm{a} . \mathrm{m}$. After lunch, he collects again from office trash cans. Government offices in Indonesia close at 2 p.m., while firms and banks shut at 4 p.m. Meanwhile, the wife cooks for the family and gossips with the neighbors. After cooking she arranges and sorts out the papers and materials and cares for the children. When the husband returns, he helps in the work. Sometimes they work until midnight either under the electric light of the museum wall or by candlelight. If the husband feels lazy he collects only once a day or perhaps remains home the whole day.

The other jobs, described in greater detail elsewhere, ${ }^{2}$ can only be outlined briefly here. The becak drivers usually rented their becak and worked either during the day or the night. They also occasionally collected paper trash. Other gelandangan owned warung--open stalls made of bamboo poles with thatched roofs with two long tables for serving food. The warung's customers were the gelandangan themselves.

In the community there was one gelandangan who worked as an agent. He bought all of the things certain of his neighbors collected and sold them on the outside. The gelandangan sold their items to him for a cheaper price than if they had sold them to outside agents themselves, but they saved time-time that could be used to collect more things. The agent also loaned them cash on credit.

Although since 1960 the prostitutes had been "legally" prohibited from living in the area and some had actually been forced to change their occupations or to leave, in 1961 I found that a community leader was protecting two prostitutes, while two other women residents were operating on their own. These prostitutes, however, did not ply their trade locally. When I revisited the area in 1963, there were five prostitutes working in a local brothe 1 owned by an army veteran who at that time was head of the RT. There were also four prostitutes who operated outside the neighborhood.

A number of the community members interviewed in 1961 had changed their jobs by 1963. Some who had been collectors of trash and used materials, for instance, had become street-sweepers for the Department of Public Works. One had become a chauffeur and one a radio mechanic's assistant. Another man had since become an assistant car mechanic. These jobs were thought to be more respectable than collecting trash.

Community Leadership

As mentioned above, by 1963, the members of the community were legal citizens of Jakarta with appropriate identification cards, and the community itself had become an RT. S., an army veteran, was appointed head of the RT by the local administrative office. ${ }^{3}$ S. had once worked at the Department of Defense complex located on the eastern

2. Parsudi Suparlan, "Gambaran Tentang Suatu Masjarakat Gelandangan jang Sudah Menetap" (A Description of a Settled Gelandangan Community) (B.A. thesis, University of Indonesia, 1961); "Orang Gelandangan di Djakarta" (The Gelandangan in Jakarta) (Unpublished paper, 1969).

3. Letters are used to indicate individuals whose anonymity the author wishes to respect. 
side of the gelandangan area, and often visited in the community. After he was pensioned from his job in 1962 he decided to live there. He built a house and in 1963 was even elected head of the community.

His electoral success was primarily due to his status as an army veteran. His military associations were believed to give him power to protect the community. He was also easily accepted by the 1ocal administrative office as head of the RT because his identification as an army veteran was.interpreted to indicate that his values were quite different from stereotyped gelandangan attitudes. He could be expected to be able to control his people in a responsible way.

But S.'s success did not mean that he was without competitors. By 1961 a limited social stratification had developed among the gelandangan, based on the type of hut owned, the type of job held, and relative wealth. Four men in particular had acquired local prominence, either because of their relative wealth, or because of their political connections.

Among the gelandangan, there is little opportunity to save money. (If at all possible, gold, watches, bicycles, and other valuable objects are saved instead of cash.) Most are chronically in debt. Local creditors therefore are necessarily figures of power and influence, and can turn their financial relationships with their neighbors into more complex patron-client ties. Two such creditor-patrons among the gelandangan I studied were D.P. and Sp. The relationship of $\mathrm{Sp}$. and D.P. was highly competitive. Each tried to have more clients than the other by showing that he treated his clients better: giving easier terms for loans or in offering higher prices for used materials, and so forth. Ethnic identity played a part in their competition as we11. Sp. frequently remarked that D.P. was a Batak, and that Bataks were not good persons because they eat dogs. He also made a joke of his rival's name by changing the last part of it from Panggabean to Panggadean (associated with the word gadai or pawn). Other members of the community then called D.P. Panggadean too. It is important to note here that for Indonesians generally names are considered sacred-magical things to be treated with respect, since they are attributes of honor and status. So when Sp. made a joke of D.P.'s name, it lowered D.P.'s prestige and made him an object of fun rather than respect. The two men did not, however, owe their leadership positions to economic power alone. They had both been active in community affairs, especially at the time when the gelandangan had been preyed on by criminals in the late 1950s. Sp. and D.P. had taken charge of organizing neighborhood security. Guards were established every night, with every male but one sharing in night duties. The two also worked out an agreement with local administrative offices and army officials in return for certain services. The gelandangan agreed to clean up the Military District office yards once a week or at special times in exchange for protection from being seized and thrown out by the police. In addition, a voluntary association was established for helping members of the community in times of sickness and death, and a community lottery was set up. The members of the lottery association contributed a specified number of rupiah a day, and once a month the total amount collected was raffled off to three winners.

A third central figure in the community, although not a real member, was U.A. This man was head of the watchmen at the National Museum. Local gossip revealed that he was initially not much liked. It was said that he had led the campaign to have all the prostitutes in the 
area change their occupations on pain of eviction, while himself keeping two prostitutes under his protection. But over time his popularity increased. His status at the museum made him a figure to respect, and his income was considerably higher than that of his neighbors. He was a leading member of the local Hansip (civil defense organization under military control) and invariably wore his Hansip uniform to remind the neighborhood of this. He also developed a close friendship with Sp. He could usually eat free at his warung, partly on the basis of common ethnic background, and partly for friendship's sake, but also because Sp. thought that association with U.A. would make it easier, when necessary, to force his debtors to pay up.

In spite of these competitors, however, $S$. remained the key figure in the neighborhood. Not only was he not a gelandangan, but his official status was decidedly higher than U.A.'s because he was a pensioned army sergeant and head of the RT. In this latter capacity, S. also had the power to control local resources. All distribution of food and other primary goods by the local administrative offices to the members of the community went through him. (I heard from some gelandangan that he manipulated the numbers in the community in order to get more foods and goods.) Like D.P. and Sp., he a1so bought distributed goods back cheap from gelandangan who needed cash. He even opened a brothel with five prostitutes, and no one dared to say anything about it in front of him.

S. was also able to use his office to weaken the position of $\mathrm{Sp}$. and D.P. For instance, he set up a warung to serve the clientele of his brothel as well as the neighborhood in general, and thus took customers away from Sp.'s warung. Simply being an official RT head enabled him to seriously undermine D.P.

Once informally considered head of the community before S.'s appointment, by $1963 \mathrm{D} . \mathrm{P}$. had lost the respect of the neighbors and was no longer an important person. He could no longer play a political role and could only reminisce about what happened in 1960 when he, U.A. and other members of the community forced the prostitutes, gamblers and thieves either to modify their ways or to move out of the area.

Yet even this structure of local power and influence was fundamentally very vulnerable. When I revisited the area in 1967, I discovered that in 1965 the whole community had been forced to leave the area by the Department of National Defense, which wanted to enlarge its buildings and thus needed extra space. The members of the community were given money to move and build huts elsewhere. I tracked down only two of these families, living in a kampong in another part of the city. They informed me that most of their old neighbors now lived in various kampong, working as street-vendors, street-sweepers, and so forth. Some, however, were still gelandangan and their locations were unknown. I was told that they had remained gelandangan because they had spent all of their money on gambling and brothels. Perhaps unsurprisingly, however, by 1968-69 a new gelandangan community had grown up along the westernmost part of the original area, along the drainage canal.

\section{Politics Among the Gelandangan}

Most of the first-generation gelandangan I studied were in the lowest class in their villages, that is poor and landless. Within the political structure of the village they were clients and had no power. 
This position shaped their values and their attitudes toward their social environment and toward the authorities. They were commonly categorized by others as humble, inactive, stupid, lazy, untrustworthy, and expected to become the servants (abdi) of others.

When such people come to such cities as Jakarta, they face a somewhat different social environment than the one they were used to in the village. An even sharper distinction between the powerless and the powerful is manifested in everyday life. Once again they are 1 iving at the bottom level of society, but the bottom seems much lower. Economically they are the poorest, socially they are the unrespected, and politically they are the powerless, but always to a greater extent than hitherto.

Their position in the city shapes their personality. As human beings with a need for self-respect, they face non-gelandangan with feelings of inferiority, jealousy, and sometimes with hatred. They often ask themselves why they are poor, dirty, and unrespected, while others are wealthy, happy, and respected. Yet they are also fatalistic and say: "Uwis nasibe urip kaja ngene," or "Sudah nasibnja hidup seperti ini" (Javanese and Indonesian for "It is our fate to live like this").

Their responses divide them into those who accept their fate, those who are frustrated and have personalities that may be said to be disorganized, and those who rebel against their fate. The first group is the majority. The emphasis is on accepting that it is their fate to be gelandangan. This does not mean that they do not wish to have better social and economic living conditions, but they believe that it is impossible. It also does not mean that they are not involved in criminal activity where there is an opportunity, but they do not organize it.

The second group are those who act abnormally in the eyes of the gelandangan and non-gelandangan. For example, they may talk and laugh to themselves, or own dolls and treat them as if they were their children, or become prostitutes for homosexual males. These are the expressions of their frustrations. However, it should be said frustration is found among almost all of the gelandangan, though its manifestations are more normal, or kept inside the heart. Even among those who accept their fate there is almost frustration.

The third group are those who rebel against their position as poor, unrespected, and powerless. They usually rebel against their poverty, because other symbols of status can be achieved through wealth. They are involved in such organized criminal activities as theft and burglary and they often exploit other gelandangan.

Because the gelandangan's position in the social stratification of Jakarta is the lowest, they can be only too easily exploited. Most of them are not considered full citizens, and so they can easily be thrown out of Jakarta during police "cleaning-operations." They are the victims of coercion by non-gelandangan, especially lower-level government officia1s (including the army and police), and by other gelandangan who have power because of criminal associations, connections with "powerful" government officials, or greater wealth. For example, the Military District Office of Tanah Abang District exploited the gelandangan community behind the National Museum in 1960-61 by ordering twenty gelandangan of this area to clean the Military District Office once a week. This order was changed in May 1961, when five people were told 
to do the cleaning every morning. The gelandangan do not receive any cash payment for this: their work is considered payment for permission to stay in the area and for the Military District office's protection from neighboring gelandangan communities and from other officials, especially the police.

Individual non-gelandangan also exploit the gelandangan. For example, lower-ranking army, police or administrative officials give permission to a gelandangan or a group of gelandangan to live in a certain area and promise to protect them. They then collect from the prostitutes they "protect." Or perhaps once a week they may "assess" a whole gelandangan community as happened in Pasar Senen. This kind of money is known as "uang keamanan" or security money. In other cases, the collection of money is done irregularly, for special occasions. For instance, U.A., as head of the guards at the National Museum, protector of the community during the 1960s, and community leader with contacts in the Military District office, occasionally collected money from the gelandangan by saying that he had lost his money, that his son was sick and needed money to go to the doctor, or that he had special expenses in marrying off one of his relatives. The gelandangan always found it hard to refuse his demands. Sometimes U.A. would visit especially the slightly wealthier gelandangan households and ask for food or cigarettes. More generally, individuals who are intermediary traders for used materials lend money to the gelandangan who in return must sell all the material they collect at a cut rate.

Exploitation among the gelandangan themselves also occurs, especially at the hands of those who have more physical strength than others. They function as brokers or agents in dealings with lowerranking army officers, police, and administrative clerks. They ask for money irregularly from the other members of the gelandangan community or exploit the women who are acting as prostitutes. In this case the men are acting as gendak or unmarried husbands whose function is to protect the woman or women from being threatened or from not being paid by theircustomers. The wealthier genandangan who are food-sellers, or intermediary buyers/sellers for the used materials exploit their neighbors by lending money to them and then buying their goods at bargain rates. The food-seller sells food on credit and must be paid at a higher price including interest. In the community I studied, one such individual was also the treasurer of the lottery association and was able to manipulate the lottery money by circulating it in his food business before it would be given to the winner of the lottery.

This exploitation and its general acceptance must be seen in the context of the social environment of Jakarta and Indonesia in general. The gelandangan are the powerless. They have no rights. There is not even any law to protect their existence in Jakarta; many of the newer members are not legally considered Jakarta citizens. They have no affiliations with political parties. Indeed they have no power to decide what political party they want to be associated with even if they so wish. In the early $1960 \mathrm{~s}$ none of the people interviewed was a member of any political party. When I returned to Jakarta in 1967 and met my old gelandangan friends the anticommunist fever was still at its peak. None of the gelandangan that I knew had been accused of being communist. They seemed not to know what communism was. Although they said that they were anticommunist, it was only because they were afraid of being called communist if they did not say so. Some new gelandangan who had just arrived in Jakarta had been members of the BTI (Barisan Tani Indonesia), a peasant organization affiliated with the Communist 
Party of Indonesia. Others were wives and children of the murdered communists or of those who were accused of being communists; but none of these gelandangan were active politically. They were just lying low to avoid being killed or persecuted.

What is the political awareness of the gelandangan in general? They are aware that they are Indonesian citizens. Whatever their definition of an Indonesian citizen they know that they are Indonesians who live in an Indonesian state governed by Indonesians. They know they are at the bottom level of society and this shapes their political attitudes. In general they behave as humble servants of superiors, doing what is expected or demanded of them in order to survive. None of the gelandangan has made any effort to gain public power or to achieve a public position in a wider network than the gelandangan community. They compete only for local power, as in the cases of D.P. and $\mathrm{Sp}$. This is understandable in view of the nature of Jakarta's urban problems, often described as the most depressing in Indonesia. The city's structure was designed for half a million people in 1930 . The population is now over six million and very few accommodations have been made for newcomers, in terms of housing or employment. The weakness of the industrial sector in the city restricts the number of jobs available to them. Some get jobs, but most do not. Because social provisions for the unemployed are absent, the situation becomes more and more pressing. It is presumed that at least 100,000 people come every year to Jakarta in hopes of improving their economic and social conditions. Until they can support themselves, they usually stay with their urban relatives. These relatives may be of the upper, middle, lower or even of the lowest social class in Jakarta. But most of the gelandangan have no relatives in Jakarta, and if they have, these relatives are usually gelandangan too.

We should not be surprised then that there are many men, women and children in Jakarta and other cities in Indonesia who live far below the poverty line. Half-naked or dressed in rumpled or torn clothes, they walk the streets and alleys of the city looking for food or scraps in trashcans and garbage heaps. Some search out cigarette butts here and there along the streets and some beg for money from people passing by on the street, or standing in line for tickets at places of public entertainment, or riding on public vehicles.

It is interesting to note that although some urban studies have been carried out in Indonesia and in Jakarta in recent years ${ }^{4}$ none of these studies mention the gelandangan people. They are referred to merely as a statistical group--the "unemployed" or "occupation unknown" (Heeren). It is important to understand, however, that unemployment is not synonymous with the term gelandangan. An unemployed person may become a gelandangan, but not necessarily so.

Gelandangan existed in Jakarta before the Second World War, but not very much was known about them. Their numbers greatly increased during the Japanese occupation, whose crushing impact was especially

4. H. J. Heeren (ed.), "The Urbanisation of Djakarta," Ekonomi dan Keuangan, VIII, No. 11 (November 1955), pp. 696-736; D. P. Milone, Urban Areas in Indonesia: Administrative and Census Concepts (Berkeley: Institute of International Studies, University of California, 1966); Lance Castles, "The Ethnic Profile of Djakarta," Indonesia, No. 3 (April 1967), pp. 153-204. 
felt in the rural areas in Java. ${ }^{5}$ Economic, political and social changes followed the establishment of the government of the Republic of Indonesia, but the flow of migrants continued and probably increased. In 1961, of the estimated 2,906,500 inhabitants of Jakarta (Census Statistical Handbook 1961) approximately 10,000 were gelandangan, and during the period of the economic collapse of the Sukarno regime in 1963-65 there were about 50,000. These numbers increased again after the fatal coup of 1965, but may have decreased since because of genera11y better aconomic conditions in Indonesia.

There have been some attempts by the local government to ease the problems of the gelandangan. For instance, the Department of Social Welfare established an institute to gather gelandangan and send them to a new place in the outer islands of Indonesia as transmigrants. They were to serve as coconut workers and unskilled laborers in Mentawai Island and Kalimantan (Borneo). This effort failed, however, due to the lack of financial support by the central government and by employer corruption. Too 1ittle food was provided during the training period and when more food was requested, the gelandangan had to pay. Moreover, many of the gelandangan who had become transmigrants preferred the city way of life; picking up leftover food and other used materials and selling them was easier than growing food, and the city offered many attractive things to see and to experience. In the end, many fled from Mentawai and returned to Jakarta, particularly after 1960. Furthermore, the transmigration program failed because more gelandangan were coming to Jakarta than there were being sent out.

There have been incidental efforts by the local government to clean up certain areas of Jakarta, particularly when foreign dignitaries come to the city. The gelandangan are then seized by the police, dumped into trucks, and taken to places outside Jakarta where they are left on the streets and roads. An effort was instituted in 1968 to limit the influx of persons moving to Jakarta. A decree was issued stating that no newcomers would be permitted to stay and live in Jakarta and become citizens. All Jakarta citizens had to carry identification cards. This only led to corruption at the lower level of the administrative system, particularly in the dispensation of identification cards. None of these efforts has solved the problems inherent in the gelandangan phenomenon or decreased the number of gelandangan in the city.

The problems of gelandangan and of urbanization in general cannot be isolated from the larger processes of cultural contact between rural and urban environments. Individuals do not become orang gelandangan because they want to or like the connotation. Gelandangan life is the result and direct consequence of economic, political and social processes which have intensified in the last decade in Indonesian society, especially on the crowded island of Java. The generally higher health standards due to modern medicine, increased education standards, proliferation of white collar jobs, and the accumulation of consumer goods as a result of the spread of the system of modern economic activity have all affected the process of social change in Java. Political conflicts and particularly the population explosion in Java are important factors in Indonesian society and specifically in the problem of gelandangan. Without heavy industrialization in Java the demands and needs of the people cannot be met.

Important in any discussion of these problems is a consideration of the economic system of rural Java which is based on sawah or wet-rice

5. Heeren, "Urbanisation," p. 704. 
agriculture. Clifford Geertz has described this system as agricultural involution. I disagree with him about the causes of this phenomenon. His description utilizes an historical perspective, emphasizing the importance of the Dutch colonial era, and pays only limited attention to present-day social dynamics which are equally causal.

Some of the rural people come to Jakarta directly from the village, trusting the news brought by a fellow-villager that there are opportunities to earn money in Jakarta more easily than by working in the village. Some come because of oppression or because of political conflict in their home villages. Many of the gelandangan in Jakarta during the 1950s and until the early 1960s came because of oppression in West Java and some places in Central Java by the Darul Islam army which was rebelling against the Sukarno regime. After the coup of 1965 some may have wished to break off their identity with the Indonesian Communist Party, or its affiliated organizations.

To view politics among these poorest of people who are themselves aware of their condition of powerlessness and accept it fatalistically is rather discouraging. We do not find vital political activity among these people as can be found in other social classes, especially the upper class. The number of gelandangan in the area behind the National Museum building who participated in politics was very limited and the political arena itself was restricted to the most local level. Those who did participate competed essentially for control of the majority of the gelandangan community. In fact, the majority of the gelandangan are victims of the political and economic actions of their superiors, either gelandangan or non-gelandangan. Yet, if they seem to accept being exploited, this attitude of acceptance must be seen in the context of their position within the social stratification of Jakarta and Indonesia in general. 